\title{
HOMENAGEM PÓSTUMA AO PROF. DR. ÁLVARO MARTINS ANDRADE
}

Em março deste ano, quando o Departamento se reuniu para fixar a data desta Jornada, o Prof. Álvaro estava presente. E, ao registrar a programação em sua agenda, para esta semana de agosto, voltou-se para mim e, brincando, disse:

- "Bem que esta Jornada poderia ser dedicada a mim, já que vai coincidir com o meu aniversário, no dia 28!"

- "Pois não", respondi no mesmo tom. "Serás devidamente homenageado e, em troca, poderás patrocinar o jantar de encerramento na sexta-feira!"

E hoje, nós estamos aqui cumprindo a nossa parte. Já, ele... ficará devendo o jantar!

A Bahia gerou o Álvaro. São Paulo o adotou. E a UNESP o encampou. Na Bahia aprendeu a engatinhar: com os pés e com a cabeça. Viveu lá de 1935 a 1947, onde aprendeu o B-A-BA e o dois +dois são quatro. Em São Paulo completou-se como pessoa e como Profissional (se é que é possivel completar-se nestas coisas!). Em Campinas, percorreu o antigo Ginásio e Colegial; na USP, fez-se Bacharel e Licenciado em Filosofia; na mesma USP, pós-graduou-se em Filosofia e em Sociologia da Literatura; na Fundação Escola de Sociologia e Política de São Paulo, pós-graduou-se em Ciências Sociais; e, na antiga Faculdade de Filosofia, Ciências e Letras de Assis, hoje Instituto de Letras, História e Psicologia de Assis-UNESP - doutorou-se em Filosofia com a tese: "Universo, Processo e Ética no Grande Sertão: Veredas. Uma análise do pensamento de Guimarães Rosa."

Se tanto recebeu, outro tanto, e até mais, soube produzir, retribuir e transmitir. Ao mesmo tempo em que estudava, lecionava Filosofia e disciplinas afins em vários Colégios e Cursos preparatórios aos Vestibulares. Depois de licenciado, passou a titular das cadeiras de Sociologia Geral e Sociologia da Educação na Faculdade de Filosofia, Ciências e Letras de Avaré.

A partir de 1969 a UNESP serviu-se de Álvaro. E terá que reconhecer que foi bem servida. Até mesmo antes de ser criada como tal, quando Assis ainda era uma Faculdade de Filosofia, Ciências e Letras, um dos vários Institutos Isolados, que depois compuseram a atual Universiciade, a UNESP era gestada com a participação de Álvaro como docente de várias disciplinas e cursos em Assis e Marília, como pesquisador, chefe do Departamento, fundador do Centro de Artes da Faculdade de Assis (com cerca de cem atividades nas áreàs de música, teatro, literatura, pintura, poesia, fotografia, etc.); fundador do Coral deste Centro de Artes, bem como do Teatro Experimental, do mesmo Centro; propôs a criação e fol o Coordenador-Geral do I Festival de Assis, realizado sob o patrocínio do Centro de Artes com a colaboração da Secretaria da Cultura, Ciência e Tecnologia do Estado de São Paulo, Prefeitura Municıpal de Assis, Secretaria da Educação e Cultura de Campinas e pelo Museu de Arte de São Paulo, festival que teve repercussão nacional através da grande imprensa do País. Fundou e instalou ainda o primeiro circo montado no "Campus" de uma Universidade brasileira, o Circo Permanente do Centro de Artes da FAFI de Assis.

Em seus dezoito anos de vida e ação na UNESP, Álvaro sempre esteve envolvido em Comissões, Chefias, Conselhos, Presidências, Câmaras de Graduação e Pós-Graduação, Bancas examinadoras, Representações, enfim, sempre um dos primeiros a ser lembrado, convidado ou votado, quando vagava algum cargo que exigisse perspicácia, combatividade, liderança e tino administrativo, ou quando surgia a oportunidade da reivindicação, da defesa, da argumentação, do convencimento.

Ele era firme, determinado e obstinado em suas propostas e convicções. Nem sempre agradava a todos, nem todos conseguiam compreender de imediato a extensão de suas propostas, posições, oposições, suposições e arrazoados. Foi dos poucos professores que tive- 
ram seu nome pichado pelas paredes desta Faculdade. Mas não levou isso como insulto. Compreendeu-o como reação própria dos vencidos e dos que não têm razão nem contra-argumento.

O Prof. Álvaro não se conteve nos estreitos limites da UNESP. O seu memorial acadêmico se compõe de várias páginas de conferências, palestras, comunicações, mesas redondas, debates, congressos, festivais, publicações, realizados por este Brasil afora e outros países da América Latina e França. A filosofia, a música, o teatro, a psicologia, a literatura, eram o seu campo de predileção e domínio.

$\mathrm{E}$, talvez, por este seu amor à arte e à filosofia, fez-se também um ser muito humano. No jogo das contradições e disque-disque, da agressividade intempestiva dos debates e posicionamentos, Álvaro sempre manteve um espaço reservado ao coração. Nos papos de corredor, nos longos telefonemas interurbanos, nas mesas de bar, interessava-lhe a pessoa, sua saúde, sua família, as doenças, as preocupações de cada um. Os telegramas de aniversário, os votos de Boas Festas, os alertas de possíveis medidas da Reitoria ou do Governo que pudessem prejudicar a vida de colegas, as idas e vindas da Reitoria para obter novas contratações, sua participação e colaboração com seus conhecimentos jurídicos para a melhoria das condições dos colegas e da própria Unidade, dão uma pequena amostra do coração de Álvaro. Sempre estava disposto a um fim de noite num restaurante, num bar, para repassar a vida e a realıdade sob o crivo do humor, da ironia, do cinismo e do ceticismo. Ele cultivava com arte o amor e o humor.

Pena que ele não ficou para o jantar do dia 28! Mas dizem que, entre a vıda e a morte, permanece o homem e a sua obra. A do Álvaro - sua obra, sua lembrança, sua presença - ficarão. É coisa que não se acaba, não se mata, não se esquece. Brota e refloresce...

Marília, 25 de agosto de 1987

(Na abertura da XII Jornada de Filosofia e Teoria das Ciências Humanas. UNESP - "Campus" de Marília).

Prof. Dr. OTTO DANA 